\title{
Model, Engage, Write, and Evaluate: A Model for Informative Writing
}

\author{
Juanita Moller \\ Department of the Early and Elementary Education \\ 340 Mandume NDemufago Ave., Pionerspark, Private Bag 13301 \\ Block X135-138 \\ University of Namibia, Windhoek, Africa \\ Tel: 61-206-4565Ｅ-mail: Juanita.Moller@gmail.com
}

Earl H. Cheek, Jr., Ph.D.

Department of Educational Theory, Policy, and Practice

Louisiana State University

223K Peabody Hall, Baton Rouge, LA 70803-7101

Tel: 1-225-578-6017Ｅ-mail: echeek@lsu.edu

Evan T. Ortlieb, Ph.D.

Early Childhood Development Center 219H

Texas A\&M University - Corpus Christi

6300 Ocean Drive Unit 5834, Corpus Christi, Texas 78412-5834

Tel: 1-361-825-2661Ｅ-mail: evan.ortlieb@tamucc.edu

Frances Steward, Ph.D.

Curriculum \& Instruction, Western Illinois University

P.O. Box 787, Macomb, IL 61455

Tel: 1-309-259-0295 E-mail: FA-Steward@wiu.edu

Received: January 29, 2012 Accepted: February 12, 2012 Published: February 1, 2012

doi:10.5296/jse.v2i1.1328 URL: http://dx.doi.org/10.5296/jse.v2i1.1328 


\begin{abstract}
Writing is regarded as a particularly demanding process involving complex higher level thinking processes combined with the demands of certain meta-cognitive skills. Since academic success may be predicted by the student's level of reading comprehension and writing skills and with the recent adoption of the Common Core State Standards, it is an ideal time for conceptualizing how to improve writing instruction for elementary students. This mixed-methods study investigated the effects of process writing instruction on the development of second and third grade students' writing abilities focusing on wide reading and inquiry, writing frames, technology netbooks, and grammar/mechanics. Results indicate that all students involved advanced at least two stages on Gunning's scale of writing proficiency, increased in number of words written, addressed problems in writing mechanics, and improved selective language use. Findings are relevant to classroom teachers, specialists, and administrators alike.
\end{abstract}

Keywords: Writing, Improvement, Elementary, Effective practices, Model 


\section{Introduction}

Students attending school today face many literacy demands. Standards-based education, mandates of standardized-test performance, and advances in technology have demanded student proficiencies in critically reading, interpreting informational texts, and communicating through informative writing. Writing is regarded as a particularly demanding process involving complex higher level thinking processes combined with the demands of certain meta-cognitive skills (Guzel-Ozmen, 2009). Students need sophisticated reading skills to access and assess various kinds of texts before synthesizing textual concepts into their writing (Moss, 2005).

Academic success may be predicted by the student's level of reading comprehension and writing skills (Graham \& Perin, 2007). Writing serves the important purpose of demonstrating knowledge; on the other hand, "poor writing proficiency should be recognized as an intrinsic part of this national literacy crisis” (Santagelo \& Olinghouse, 2009, p. 1).

Reports such as those of the National Commission on Writing (2003, 2004, 2005) elevated public awareness regarding the importance of writing proficiency. The National Council of Teachers of English (NCTE, 2009) furthered that writing instruction for teachers of students in the $21^{\text {st }}$ century addressed three challenges, namely to develop new models of writing, design a new curriculum to capture the developed models, and create models to serve as teaching strategies (Yance, 2009). These reports provide the kindling for conceptualizing about how to improve writing instruction for all youth.

One elementary school in the Midwest took this challenge, setting out to advance their own methods of instruction towards improving their students' writing. With the decline of student population numbers at Garland Elementary (pseudonym), the administrator and teachers worked closely together to plan curricular reform to utilize Title II funding for needed resources, which included the acceptance of a Fulbright Scholar to serve in the roles of graduate project teacher and participant observer in a mixed method design study involving second and third graders. Of particular emphasis were those students that needed to be prepared for success on the end-of-the-year annual assessments incorporating writing tasks; after a reflective evaluation of the previous year's student test scores, it was apparent that there was a critical need for an expansion of the students' inquiry and process writing skills on expository reading and informative writing tasks.

Through an exhaustive exploration of best practices in writing instruction, one notion was clear-explicit instruction would provide the critical guidance and structure to the writing efforts and skills of the students. Yet, additional research was needed to determine which instructional practices had the greatest effect on third grade writing improvement at Garland Elementary. The participant observer postulated, "How can writing instruction be applied to motivate and intensify the quality of young students' informative writing skills?” The hypothesis was formulated that writing instruction, when effectively applied, could motivate and intensify young students' informative writing skills.

\section{Theoretical Framework}

Knowledge is constructed from experiences that combine to form internalized schemata 
(Berk, 2006; Miller, 1993, Newman \& Newman, 2007). These social interactionist learning experiences are accompanied by the use of private speech to regulate task-related behavior (Berk \& Winsler, 1995). Children develop cognitively through cultural and social interaction with knowledgeable others to reach their proximal development levels; these individuals serve as models to scaffold others to higher levels of knowledge and reasoning (Miller, 1993; Vygotsky, 1978). Theorists such as Erikson, Rogers, and Maslow have maintained that the development of a positive self concept is the key to successful self-actualization.

Children in this age group must experience success and being productive (a sense of industry) to counter feelings of inferiority when failure ensues (Miller, 1993). Adult-child relationships aim to instill children with a positive regard and the capacity for self-direction (Prochaska \& Norcross, 2010). Adults assume the responsibility to support children's efforts to develop self-control over their actions and behavior, ensuring a rich environment and freedom to explore for optimal intellectual growth (Miller, 1993).

Socio-cultural theories maintain that the cognitive needs of elementary children are as follows: (a) stimulation and nurturance; (b) authentic activities; (c) enjoyable, meaningful learning; (d) learning challenges; (e) higher order thinking skill development; (f) successful self-esteem development; (g) productivity and success in what they were DOIng; and (h) opportunities to develop personal interests and personal views (Charlesworth, 2011). If educators are to be successful in the academic development of skills like writing, they must plan instruction with these notions in mind.

\section{Literature Review}

\subsection{Historical Nature of Writing}

Historical focus has been placed on reading which served as a provision for students to receive information. In the $20^{\text {th }}$ century, the strides made in scientific knowledge developed a need for adequate writing skills to describe and explain phenomena. Initially (until 1940s), the skill and assessment of writing were focused on composition writing and penmanship. Alongside the Progressivism Movement came the development of the Experience Curriculum in English (developed by NCTE in 1935) that expanded language arts to include everyday genres, letters, recipes, diaries, reports, reviews, summaries, and stories. Compositional writing was then used to explore interests, not just as a knowledge-making-activity (Yance, 2009). Compositional writing as a skill was not overtly taught, but prescribed and corrected. The final product was assessed, and the writing process was not emphasized (Jasmine \& Weiner, 2007).

Between the 1960s and 1980s, the concept of Process Writing developed under the hands of Donald Graves in 1983 and Lucy Calkins in 1986. It included the stages of invention, drafting, peer review, reflection, revising and rewriting, and publishing. Digital technologies in the $21^{\text {st }}$ century enhanced the possibility of becoming a writer. Through chat rooms, emails, Facebook, Twitter, and blogs, students became writers not only through classroom instruction, but also 'extracurricular social co-apprenticeships' (Yance, 2009, p. 5).

Although fourth graders were not tested for writing skills in 2007 or 2009 according to the National Assessment of Educational Progress (NAEP) reports, writing was regarded as “one 
of the most important skills that young people can acquire and develop throughout their lives” (NAEP). The NAEP writing assessment now includes the following three purposes for writing to ensure that it reflects writing genres attended to in classroom instruction: Narrative writing (writing a story (events, steps, and procedures) — writers incorporated their imagination and creativity in the production of stories or personal essays; Informative writing (informing the reader)—writers provided the reader with information, e.g., reporting on factual information or analyzing concepts; and Persuasive writing (persuading the reader)—writers sought to persuade the reader to take action or to bring about change.

A balance between the skill of reading informative texts and writing informative texts should be stressed. Moss (2005) emphasized the importance of exposing elementary grade students to expository texts to lay a solid foundation for familiarity with informative texts that are increasingly featured in later grades. Expository texts also serve as reading motivation, especially for boys (Marinak \& Gambrell, 2010). In the first three grades and in higher grades, students are supplied with new knowledge fields and areas critically important to understand the concepts of history, mathematics, and science (Yance, 2009). Students learn the skill of evaluating information that is essential for this information age where so many genres, media types, and technological sources provide access to information. Susan Neumann (2001), former U.S. Assistant Secretary of Education, stated that if young students want to write, think about, or solve problems, they need something to write about or think about or have a problem to solve. "In short, important learning processes require content knowledge" (Neumann, 2001, p. 473). In “The Neglected 'R': The Need for a Writing Revolution," the report issued by the National Commission on Writing (2003), it argues: "If students are to make knowledge their own, they must struggle with the details, wrestle with the facts, and rework raw, dimly understood, conceptual information into a communicative language. In short, if students are to learn, they must write” (Caperton, 2009, p. 1).

\subsection{Instructional Practices for Teaching Writing}

Reading and writing are meaning-making language activities (Oswald, Newton, \& Newton, 2010). These processes are reciprocal, reinforcing, learning experiences. Attaining an instructional balance between basic writing skills and process writing strategies is critical to maximize student learning (Cutler \& Graham, 2008). According to Rogers and Graham (2008), effective instruction of process writing includes adherence to writing stages, grammar conventions instruction, various types of sentence formations, and paragraph construction.

Self-Regulated Strategy Development (SRSD) model, a cognitive strategy approach developed by Harris and Graham (1996), is a process of explicit strategy instruction and extensive self-regulated instruction that is formed upon the following stages: (a) Develop background knowledge, for example the writing purpose and its process; (b) Discuss the strategy, including benefits and expectations, for example retell and review the first stage skills; (c) Model the strategy for example talking during writing to follow thinking processes; (d) Memorize the strategy (Student), Support the strategy collaboratively (Teacher \& Class), maintaining the goals and criteria established for success; and (e) Utilize independently the strategy. These instructional stages are comprised of four general strategies that students in this study were taught to use independently: (a) Self-regulated, goal setting-to ensure all the criteria for the specific strategy were in place; (b) Self-instruction, writing talk aloud; (c) 
Self-monitoring, self-statements for example, what comes next, does it make sense; and (d) Self-reinforcement for example I really like that part. Then, confirm: "My paragraph has the topic sentence and supporting sentences” (Graham, Harris, \& Mason, 2005).

Santagelo and Olinghouse (2009) recommend a number of research-based instructional methods and approaches: (a) Process Writing that supported students to learn by DOIng regular writing tasks; (b) Explicit instruction for struggling writers in planning, revising, editing, and specific cognitive strategies during each process writing stage; (c) Inquiry activities that guide students' development of writing ideas, while models of good writing showed students what was expected; (d) Simultaneous reading and writing instruction ensure that students learn different text structures within different genres; (e) Goal setting help students focus on a specific aspect of their writing; (f) Authentic, thoughtful, writing activities motivate students and included clear purposes, real world relevance, and personal meaning; (g) Word processing (technology) enhances the length and quality of writing especially for struggling students.

Other authors have concluded that writing is a complex skill (Alber-Morgan, Hessler, \& Konrad, 2007; Graham, Harris, \& Mason, 2005; Holloway, 2010; Olinghouse \& Santagelo, 2010) ; furthermore, it is necessary for classroom teachers analyze students' needs in order to meet the high expectations of writing. Mini-lessons and/or modeling are two methods by which teachers can enhance students' knowledge and skills and bring awareness regarding the variety of writing components. Weaver and Bush (2006) found that English language teachers had superior results by focusing on key grammatical options and skills (e.g., sentence combining) through actual content writing during process writing, making grammar conventions and mechanics more relevant for students.

Mini-lessons in teaching mechanics or paragraph composition, capitalization, and sentence structures are effective with students of all ages. Reader or audience awareness is a powerful tool (Alber-Morgan, Hessler, \& Konrad, 2007; Holloway, 2010). Students experience writing as authentic and write with more effort on the hand written compositions. Holloway (2010) conducted a study on a research-based writing procedures geared towards assisting fourth graders understand that written feedback is not immediate as with verbal feedback. Students revised informative paragraphs in a referential communication activity (referred to oral conversation with fine-tuning a message that gave feedback or responses, or clarified messages). Thus, the writer met the challenge of describing, pointing out, classifying, clarifying, and giving examples and detail that enabled the reader to read with clarity. During the stage of revision, the writer re-read, re-planned and re-represented a described image as s/he were the reader to determine whether the content was clear and the text meaningfully structured. This required meta-comprehension ability since it focused on the link between the text and its context in order to meet expectations readers had for certain forms of text. Writers took the perspective of the reader. Motivational suggestions also allowed for the following improved writing approaches: (a) Students worked at their individual paces; (b) Peers shared writing; (c) Teachers modeled enjoyment; (d) Publishing was featured strongly; (e) Teachers were encouraged to share personal writing to foster a love and enjoyment of writing; and (f) School and home connections improved parent communication about children's writing progress and parents asked to listen to children's 
compositions.

\section{Methods}

\subsection{Contextual Factors}

The K-8 school was located in the Midwest with a student to teacher ratio of approximately 9:1. Most classes were multi-grade; for example Kindergarten and first grade were a combined class based on the small size of the school. Furthermore, there were no additional aides, assistants, special education teachers, reading specialists, or psychologists. At the time of this study, no students were receiving Response to Intervention (RTI) either. In the past, a Title 1 teacher was used to serve students who needed support with reading. All five second and third graders were Caucasian; none qualified for special services.

\subsection{Procedures}

The research project consisted of the following phases: (a) observe and assess existing needs, (b) choose a focus area for instruction (c) select three focus students, (d) plan and implement a two-week unit of instruction (students developed and presented instructional compositions, PowerPoint slides, posters, and games to parents and teachers). Using instructional writing strategies, the following procedures were implemented: (a) mini lessons; (b) individual conferencing; (c) modeling; (d) peer support; (e) revising and editing checklists; (f) writing frames; (g) reading experiences; and (h) product development. Teachers utilized these strategies in an attempt to measure their summative effect, as writing requires an eclectic array of skills to be integrated and applied to new writing demands (Alber-Morgan, Hessler, Konrad, 2007; Ranker, 2009).

\subsection{Instructional Technology}

After observing, videotaping lessons, and writing anecdotal notes in journal writings, the participant observer planned and taught a two-week unit of lessons focusing on developing students' proficiencies in writing. Students used expository texts and netbook laptops to gather detailed information, used search skills, and categorized keywords and ideas. The same objectives served in the pre-and post test to establish the rate of success of the instruction unit.

Objective 1: The students will write a composition that is based on wider reading (Fiction and non-fiction) in order to gather content facts.

Objective 2: The multi-leveled writing skills of the students will be developed in a composition adhering to the correct grammar mechanics and conventions (sentence construction, message clarity, fluency, voice style, and unique words).

Objective 3: The students will develop and write an informative composition adhering to the process writing stages [pre-writing (writing frames for organizational structure), rough draft, revising and editing partners, final copy, and publishing] and components of each [Introduction (meaningful purpose, transitional sentence, categorical keywords, audience awareness), Middle, and Conclusion].

Objective 4: The students will be able to use technology (netbooks) to gather information and present the content (PowerPoint) of the compositions.

The specific skills taught under each objective during the two weeks unit of instruction were 
carefully selected and implemented in order to gradually develop knowledge, attitudes, and skills for the culminating product. Skills were rated for difficulty level: (1) indicated fairly easy thought processes; (2) required moderate cognitive input; (3) needed higher-order cognitive input.

\subsection{Data Analysis}

In order to determine the extent to which the implementation of the new techniques (reading widely, using technology, and planning on writing frames) impacted student learning, multifactor analysis was utilized: (1) qualitative data (observation descriptions of student performance in daily journal entries, summative reflections, and descriptive data on a special designed matrix); and (2) quantitative data (pre-and post composition evaluations) were analyzed using multiple measures.

For content validity and qualitative purposes, each student's descriptive performance data was recorded by the participant observer for the four observations that were written daily in journals and comments of pre-and post-assessment. Adhering to Mayring's (2003) approach, the content validity (explication, transformative research) helped the participant observer to develop trustworthiness as determined with the connections between observation notes and students' writing, thus improving the insights and interpretation of the details and complexity of the writing process (Kohlbacher, 2006).

One qualitative assessment instrument was used to compile the observation and assess (pre-and post) descriptive comments for each objective. The qualitative assessment instrument was Descriptors of Selected Students and Skills Objectives. Each student was selected for the type of demonstrated writing performance and work habits observed. Student 1, the highest performance; Student 2, the weakest proficiencies; and Student 3, average skills. The skill objectives were to improve writing from wider reading, using correct grammar mechanics and conventions, using a writing frame in process writing, and applying technology skills in a PowerPoint slideshow.

Three quantitative assessment instruments were designed: (a) A-typical Student 1, Formative Assessment Data: Objective 1, 2, 3, 4 and Writing Stage (Score), (b) Type/Token Ratio and Word Count, and (c) Writing Score: Selected Students and Class Means. Each descriptor for the objectives indicated a proportion of value (9.09\%). A student who obtained a maximum score of 5 for each skill attained "exceeds expectations". A score of 4 indicated "Meets Expectations”; a score of 3 “Approaching Expectations”; a score of 2 "Below Expectations”; and a score of 1 "Not approaching Expectations". The means of each student and class were recorded for each objective.

\subsection{Validity}

The writing levels were determined according to the tool's scoring criteria, namely: 0-5 score = basic level; 6-10 score = functional level - (the aim of this writing workshop); 11-15 score $=$ proficient (high school level); 16+ score = advanced (author level) (Whitaker, 2003). In addition the type/token ratio was a measure used to determine the word count, word variety, and word repetition in the first 50 words in the student's text (see Polloway, Miller, \& Smith, 2004). The inclusion of these criterion-referenced assessment instruments allowed for a quantitative objective comparison between pre- and post test compositions that was accurate, 
consistent, and fair for each student. The purpose was to determine each student's growth between the pre-and post-test and to determine how many of the needs were attended to during the two weeks instruction unit.

\section{Results}

The results of the project were inspiring. Scaffolding in the form of mini-lessons, modeling, process writing, wider reading, technology use, and activities related to their topics, led each student to reach the next level of Gunning's (2006) stages. For instance, Student 1, scores improved from stage 4 (the experimenting writer) to stage 6 (the extending writer); student 2 improved his scores from stage 3 (the focusing writer) to stage 5 (the engaging writer); and student 3 advanced her scores from stage 2 (the developing wrier) to stage 4 (the experimenting writer). Thus, each student advanced his or her skills by two stages (see Table 1).

For objectives 1, 2, 3, and 4, the participant observer analyzed writing for interpretive descriptors for each student's writing details, traits, work habits, or miscues. An analysis of the three students' performance in descriptors of writing and scores enhanced the insightful interpretation of quantitative scores. Progress on the pre-assessment to the post-assessment was evident with in a reduction of spelling errors as well as an increase in the number of written words, descriptions, audience awareness, good ideas and explanations, voice tone, reading rate, message clarity, purpose setting, and successful technology application (see Table 2).

An example of Type/Token Ratio and Word Count of the formative assessment is exemplified with the scores of Student 1. Accuracy of the grammar and mechanics is depicted for type/ token ratio, and the 8-count rule is applied for the Word Count (see Table 3).

Each student's and the class' post assessment writing mean were calculated for each objective. All means ranged from 4.53 to 4.86 out of the maximum score of 5 (see Table 4).

\section{Discussion}

This research project demonstrated that second and third graders read expository books and wrote informative compositions of a high quality. Using a structured format (writing frame), students in this focused study surpassed expectations by combining and providing enriched reading experiences with the opportunity to write about their gained knowledge. Oswald, Newton, and Newton (2010) expressed the thought that as children grow and develop (gained knowledge), talking and writing become the means of shaping, ordering, and denoting their experiences that further lead to increased understanding. The act of writing about a topic of interest ensured student involvement and brought about gains in learning; thus, reading and writing became meaning making activities. Reflecting on the literacy events during the two-week instructional unit, success was accomplished in the use of writing workshop, the enhanced value of wider reading, process writing (structural framework and formative interaction), mini lessons, and the inclusion of technology.

The success of the students' compositions was attributed to the writing workshop climate in the class at the time. The writing workshop structured the environment, encouraged writers to take risks and learn their craft, and gave students' direct instruction in writing through different approaches (whole class, small group, and individual support) according to specific needs. It 
also encouraged independence, provided choice within a framework, provided a scaffolding support system to each individual through frequent response, and used literature to teach students the skills needed to write proficiently. This semi-structured environment led to the development of students' skills; students could select what they wanted to write about concerning a certain theme from their subject Health Education. Fiction books were partially read aloud and snippets from non-fiction texts were read aloud to spark their curiosities. After students identified a focus, expository books were self-selected according to predetermined topics to supplement and enhance the knowledge of the school textbook. Internet searches were also conducted using wireless connected netbooks in class. Like Bitter, O’Day, Gubbins, and Socias, (2009), investigators also found reading comprehension and writing to be reciprocally strengthening skills that should be taught concurrently.

Since additional reading was included in the two weeks unit of writers' workshop, students' knowledge and ability to express and retain what they had read was reflected in the substantial increase in words written and the quality of the content of the informative compositions. Wider reading was beneficial as trade books and the internet fed their curiosity. Students were eager to share the information that they had acquired through reading and writing. Read alouds and individual readings of fiction and nonfiction books relating to their topics motivated students and made their writing authentic and purposeful, prompting them to share the interesting information.

The decline in spelling and grammatical errors served as verification that revision and editing with peers were meaningful stages in process writing. By first drafting a plan on the writing frame, students wrote compositions in a well constructed manner, which included topical paragraphs and ordered disclosure of content. Peer support in the form of buddy (peer) revision (discussion and checklists) and teacher conferences encouraged high-quality compositions that were error free and pleasing to read. Cutler and Graham (2008) in their national survey stated, "Of all the teachers, only $2 \%$ never engage in process writing instruction” (p. 913). This depicts how prevalent process writing is towards helping students achieve success.

Students were highly motivated and came alive when they worked on the netbooks and searched for content information. Edward-Groves (2011) commented that "technologization and globalization" have induced the need for education to include technology and allow students to "design, produce and present multimodal texts as representations of learning" (p. 49). During the two weeks unit of instruction, the preparation of their PowerPoint slides and the confidence level of the focus students during presentations of their self-selected topics and compositions eludes to how valuable computers were as incentive tools. Children found it exciting to search for information regarding their topics by selecting the right keywords to narrow down the responses. The use of internet searches had enhanced the students' writing since their compositions had both critical facts and details. By presenting their written information through PowerPoint slides, the content knowledge was reinforced in an authentic way.

Additionally, students' awareness that there was an audience who came to listen to their presentations and read their compositions was upon reflection a very strong motivator for developing worthy academic products for authentic reasons. Students regularly stated that 
they did not want any red marks from the teacher in their final compositions, because others were going to read it.

The inclusion of the pre-assessment task assisted in identifying the crucial aspects regarding writing that needed to be addressed and paved the way for decision making for the two-week unit of instruction. It clarified the inclusion of mini-lessons and the timing of the writing workshop. Based on the pre-assessment, the decision was made to engage in content searches as well as wider reading for more information to develop the compositions and interest in their topics. It was observed that students found it difficult to synthesize or discern essential information from nonessential information. These were higher order thinking skills that needed further prompting, which were recognized in their compositions and presentations. In the future, more attention and longer time are needed to instill these skills.

As graduate project teacher or participant observer of the two-week unit of instruction, the following strengths were identified: (a) An ability to work on the students' levels; (b) The encouragement and guidance of successfully completing their writing frames; (c) Completions of their compositions to a high level of accomplishment; (d) Planning was sequentially well structured, and (e) Each activity had a cumulative effect of attaining the goals. The inclusion of wider reading and technology tremendously catapulted the standard of the culminating products. The outcomes exceeded expectations for all students.

\subsection{Outcomes}

This research project focused on enhancing the informative writing skills of second and third grade students. After a writing example was obtained as a pre-test, a two-week unit of lessons was developed using a workshop approach with process writing and instructional mini-lessons were recommended by various studies (Alber-Morgan, et al., 2007; Cutler \& Graham, 2008; Helzel \& Greenberg, 2007; Jasmine \& Weiner, 2007; Ranker, 2009; Rogers \& Graham, 2008; Roger \& Graham, 2008; Santagelo \& Olinghouse, 2009).

Explicit instruction through mini-lessons was followed up by the stages of process writing (planning, drafting, revising, editing, and publishing). The outcomes of the two-week unit of instruction were recorded on the designed tables. From the results, it was clear that the whole class benefitted from the writing workshop. The greatest advancement was in content (objective 1) and audience awareness (objective 3) at 45\% (2.75 to 5 out of 5) with grammar mechanics (objective 2) and organization and structure (objective 3) following by an improvement of $41 \%$ (2.75 to 4.8 out of 5). Another significant growth took place in amount of words (mean of 43 to 270). The mean increase was 227 words. It was noted that the type-token ratio of word variety had also shown development $\left(M_{\text {pre }}=28.5\right.$ to $\left.M_{\text {post }}=31.4\right)$. However, in order to sustain this new level of achievement regular, consistent application of the strategies using the writing frame for pre-planning, wider reading, audience awareness, and choice in topics for writing was needed. All objectives and criteria specified needed fortification. A solid foundation was formed, but needed constant reinforcement and practice to enable exemplary writing skills. The involvement of parents by having them read what their child had written served as a motivator for writing and audience awareness.

The summarized (synthesized) data revealed that the three students had shown a growth rate of 54\% for content, (objective 1) 33.3\% for grammar and language usage (objective 2 skills), 
and $39.3 \%$ for organization and structure (objective 3 skills). The scores of the whole class reflected a $45 \%$ growth in content, $38.8 \%$ growth in grammar and language usage, and $39.3 \%$ in organization and structure.

\subsection{Limitations}

The duration of the writing intervention (three weeks) was a limitation in that students were unable to continue using wider reading and the writing frame application with other subjects under the direct guidance of the participant observer with the exact method. Another potential factor is the level of in-service training of teachers in the writing process and the lack of follow up assistance for encouragement of efforts and workability of the student learning techniques. Faculty members would benefit from continued professional development in process writing and use of the writing frame.

\subsection{Conclusion}

The techniques and methods used (wider reading, writers' workshop, process writing, mini lessons, and technology inclusion) demonstrated that indeed these techniques and methods were responsible for strengthening young students' informative reading and writing. The fact that a two-week unit of planned instruction was based on the pre-writing organization (writing frames) outcomes and best practices from the literature review confirmed the instructional benefits. Students' growth provided the teacher an evidence base that the instruction and methods met the needs of the students. Students exemplified an increase in number of words written, addressed problems in writing mechanics, and improved selective language use (e.g., the average word increase for the focus students was 174 words and for the whole class overall 134 words). In addition, no spelling or grammatical errors were found in the final writing copies. Appropriate and effective methods inclusive of written feedback rendered the development of writing skills in these second and third graders, providing further justification for the need of research-based practice and evaluation.

\section{References}

Alber-Morgan, S. R., Hessler, T., \& Konrad, M. (2007). Teaching writing for keeps. Education and Treatment of Children, 30(3), 107-128. http://dx.doi.org/10.1353/etc.2007.0012

Berk, L. E. (2006). Child development ( $7^{\text {th }}$ ed.). Boston: Allyn and Bacon.

Berk, L. E., \& Winsler, A. (1995). Scaffolding children's learning: Vygotsky and early childhood education. Washington, DC: National Association for the Education of Young Children.

Bitter, C., O’Day, J., Gubbins, P., \& Socias, M. (2009). What works to improve studentliteracy achievement? An examination of instructional practices in a balanced literacy approach. Journal of Education for Students Placed at Risk, 14, 17-44. http://dx.doi.org/10.1080/10824660802715403

Calkins, L. (1986). The art of teaching writing. Portsmouth, NH: Heinemann.

Caperton, G. (2009). Words have no borders. The National Commission on Writing.

Retrieved

from: http://www.nwp.org/cs/public/download/nwp_file/12496/Words_Have_No_Borders.pdf? 
$\mathrm{x}-\mathrm{r}=$ pcfile_d

Charlesworth, R. (2011). Understanding child development. Australia: Wadsworth Cengage Learning.

Cutler, L., \& Graham, S. (2008). Primary grade writing instruction: A national survey. Journal of Educational Psychology, 100(4), 907-919. http://dx.doi.org/10.1037/a0012656

Edwards-Groves, C. J. (2011). The multimodal writing process: Changing practices in contemporary classrooms. Language and Education, 25(1), 49-64. http://dx.doi.org/10.1080/09500782.2010.523468

Graham, S., Harris, K. R., \& Mason, L. (2005). Improving the writing performance, knowledge, and self-efficacy of struggling young writers: The effects of self-regulated strategy development. Contemporary Educational Psychology, 30, 207-241. http://dx.doi.org/10.1016/j.cedpsych.2004.08.001

Graham, S., \& Perin, D. (2007). Writing next: Effective strategies to improve writing of adolescents in middle and high schools - A report to Carnegie Corporation of New York. Washington, DC: Alliance for Excellent Education.

Graves, D. (1983). Writing: Teachers and children at work. Portsmouth, NH: Heinemann。

Gunning, T. G. (2006). Assessing and correcting reading and writing difficulties.Boston, MA: Pearson.

Guzel-Ozmen, R. (2009). Modified cognitive strategy instruction: An expository writing strategy. Intervention in School and Clinic, 44(4), 216-222. http://dx.doi.org/10.1177/1053451208328829

Harris, K. R., \& Graham, S. (1996). Making the writing process strategies work for composition and self-regulation. Cambridge, MA: Bookline Books.

Helzel, L., \& Greenberg, D. (2007). Helping struggling writers succeed: A self-regulated strategy instruction program. The Reading Teacher, 60(8), 752-760. http://dx.doi.org/10.1598/RT.60.8.5

Holliway, D. (2010). A literacy task to assist reader awareness in children's informational writing. Language and Education, 24(2), 101-116. http://dx.doi.org/10.1080/09500780903121641

Jasmine, J., \& Weiner, W. (2007). The effects of writing workshop on abilities of first grade students to become confident independent writers. Early Childhood Education Journal, 35(2), 131-139. http://dx.doi.org/10.1007/s10643-007-0186-3

Karsbaeck, B. (2011). Writers workshop does it improve the skills of young writers? Illinois Reading Council Journal, 50(2), 3-14.

Kohlbacher, F. (2006). The use of qualitative content analysis in case study research. Sozialforschung Forum: Qualitative Social Research [On-line Journal], 17(1), 9-13. Retrieved from http://www.qualitative-research.net

Marinak, B. A., \& Gambrell, L. B. (2010). Exploring the elementary gender gap.Literacy Research and Instruction, 49(2), 129-141. http://dx.doi.org/10.1080/19388070902803795

Mayring, P. (2003). Qualitative Inhaltsanalyse, Grundlagen und Techniken (8 ${ }^{\text {th }}$ ed.). Weinheim: Beltz, UTB. 
McMaster, K. L., \& Campbell, H. (2008). New and existing curriculum-based writing measures: Technical features within and across grades. School Psychology Review, 27(4) 1-28.

Miller, P.H. (1993). Theories of developmental psychology (3rd ed.). New York, NY: W. H. Freeman.

Moss, B. (2005). Making a case and a place for effective content area literacy instruction in the elementary grades. The Reading Teacher, 59(1), 46-55. http://dx.doi.org/10.1598/RT.59.1.5

National Center for Educational Statistics (NCES). (2007, 2009). National Assessment of Educational Progress (NAEP) 2007, 2009 Assessment. Retrieved from http://nces.ed.gov/nationsreportcard/writing/moreabout.asp

National Commission on Writing. (2003, April). The neglected R: The need for a writing revolution. Retrieved July 31, 2006, from http://www.writingcommission.org/report.html

National Commission on Writing. (2004, September). Writing: A ticket to work... or a ticket out: A survey of business leaders. Retrieved July 31, 2006, from http://www.writingcommission.org/report/html

National Commission on Writing. (2005, July). Writing: A powerful message from state

government. $\quad$ Retrieved January 21, 2011, from http://www.writingcommission.org/report/html

Neumann, S. B. (2001). The role of knowledge in early literacy. Reading Research Quarterly, 36, 468-475. http://dx.doi.org/10.1598/RRQ.36.4.6

Newman, B. M., \& Newman, P. R. (2007). Theories of human development. Mahwah, NJ: Erlbaum.

Olinghouse, N. G., \& Santagelo, T. (2010). Assessing the writing of struggling learners. Focus on Exceptional Children, 43(4), 1-27.

Oswald, R., Newton, E., \& Newton, J. (2010). Using written response for reading comprehension of literary text. In B. Moss and D. Lapp (Eds.). Teaching New Literacies in Grades K-3: Resources for $21^{\text {st }}$ century classrooms (pp. 246-255). New York, NY: Guildford Press.

Polloway, A., Miller, L., \& Smith, T. E. (2006). Language instruction for students with disabilities. Denver, Co: Love Publishing Co.

Prochaska, J. O., \& Norcross, J. C. (2010). Systems of psychotherapy: A transtheoretical analysis $\left(7^{\text {th }}\right.$ ed.). Pacific Grove, CA: Brooks \& Cole.

Ranker, J. (2009). Student appropriation of writing lessons through hybrid composing practices: Direct, diffuse, and indirect use of teacher offered writing tools in an ESL classroom. Journal of Literacy Research, 41(4), 393-431. http://dx.doi.org/10.1080/10862960903340124

Rogers, L. A., \& Graham, S. (2008). A meta-analysis of single subject design writing intervention research. Journal of Educational Psychology, 100(4), 879-906. http://dx.doi.org/10.1037/0022-0663.100.4.879

Santagelo, T., \& Olinghouse, N. G, (2009). Effective writing instruction for students who 


\section{Macrothink}

have writing difficulties. Focus on Exceptional Children, 42(4), 1-20.

Vygotsky, L. S. (1978). Mind and society: The development of higher psychological processes. Cambridge, MA: Harvard University Press.

Weaver, C., \& Bush, J. (2006). Grammar intertwined throughout the writing process:

An "inch wide and a mile deep." English Teaching: Practice and Critique, 5(1), 77-101. Retrieved from: http://education.waikato.ac.nz/research/files/etpc/2006v5nlart5.pdf

Whitaker, S. R. (2003). Word play: Building vocabulary across texts and disciplines grades 6-12. Portsmouth, NH: Heineman.

Yance, K. B. (2009). Writing in the $21^{\text {st }}$ century. A report from the National Council of Teachers of English. Retrieved from http://www.ncte.org

\section{Copyright Disclaimer}

Copyright reserved by the author(s).

This article is an open-access article distributed under the terms and conditions of the Creative Commons Attribution license (http://creativecommons.org/licenses/by/3.0/). 